\title{
Faktore by die aankoop van 'n motor vir privaatgebruik
}

\author{
P.J. du Plessis en P.L.S. Ackermann \\ Skool vir Bedryfsleiding, Universiteit van Suid-Afrika, Posbus 392, Pretoria, 0001 Republiek van Suid-Afrika
}

Accepted 2 February 1987

\begin{abstract}
In this study an attempt is made to establish underlying dimensions from the various evaluation criteria a consumer considers when buying a motor vehicle. The sample consists of 902 consumers of all race groups in mainly metropolitan areas in South Africa who bought a new or used car for private use during the period December 1985 - May 1986. With the aid of principal-factor analysis 12 underlying dimensions out of 65 evaluation criteria were identified, namely: dealer orientation. maintenance, space convencience, driving comfort, mechanical performance, appearance, social influence, manufacturing, choice reinforcement, technical priority, discount and reputation. These factors may serve as a guideline for marketing managers to develop strategies regarding benefit segmentation, promotion and positioning.
\end{abstract}

\begin{abstract}
In hierdie studie word daar bepaal of daar onderliggend aan die groot getal evalueringskriteria wat ' $n$ koper van 'n motorvoertuig oorweeg, 'n kleiner getal dimensies geïdentifiseer kan word, gegrond op die koper se persepsie van die relatiewe belangrikheid van die kriteria. Die steekproef bestaan uit 902 verbruikers van alle rassegroepe in hoofsaaklik metropolitaanse gebiede in Suid-Afrika wat tussen Desember 1985 en Mei 1986 'n nuwe of gebruikte motor vir privaatgebruik gekoop het. Met behulp van hooffaktorontleding is daar 12 onderliggende dimensies uit die 65 evalueringskriteria geïdentifiseer naamlik: handelaaaroriëntasie, instandhouding, ruimtegerief, bestuursgemak, meganiese werkverrigting, voorkoms, sosiale beïnvlocding, vervaardiging, keuseversterking, tegniese voorkeure, diskonto en reputasie. Hierdie faktore kan as riglyn by die ontwikkeling van bepaalde bemarkingstrategieë soos voordeelsegmentasie, posisionering en reklame deur bemarkers gebruik word.
\end{abstract}

* Aan wie korrespondensie gerig moet word

\section{Inloiding}

Dit is byna ' $n$ gemeenplaas om te konstateer dat ' $n$ passasiersmotorvoertuig 'n noodsaaklikheid in die moderne lewe geword het. Vir 'n ontwikkelende land soos SuidAfrika wat deur relatief lang afstande gekenmerk word, is die motorbedryf van kardinale belang. ' $n$ Motor is ' $n$ duursame artikel en verteenwoordig, naas 'n woning, normaalweg die belangrikste en grootste enkeluitgawe wat 'n verbruiker aangaan.

In die motorvoertuigmark vertoon kopers 'n heterogene samestelling ten opsigte van ras, kultuur, geslag, ouderdom, inkomste, waardes, houdings en motiewe. Die vraag na motors is in die langtermym onder andere afhanklik van die bevolkings- en inkomstegroei van verbruikers. Ander faktore wat ook hier ' $n$ rol speel is deur die Raad van Handel en Nywerheid (1960:2-3) geïdentifiseer as veranderinge in smaak (voorkeure) en gewoontes by verbruikers. ' $n$ Verandering in die smaak of voorkeure van verbruikers kan meebring dat mededinging tussen motorvervaardigers feller raak. Vir die ontwikkeling van gepaste bemarkingstrategieë deur motorvervaardigers is kennis van verbruikersgedrag 'n noodsaaklike voorvereiste.

Verbruikersgedrag kan gedefinieer word as: besluitnemingseenhede (individue sowel as gesinne) se gedragspatrone wat die besluitnemingsproses, vir die verkryging van behoeftebevredigende produkte, idees en dienste voorafgaan, bepaal en naloop (Du Plessis 1986:39).

Voorkeure en gewoontes van verbruikers (kopers) word in die besluitnemingsproses by die aankoop van 'n motor gemanifesteer. Een van die fases in die verbruikersbesluitnemingsproses is die evaluering van produkte. Kriteria wat in die evalueringsfase gebruik word, behels sowel fisiese produkattribute as subjektiewe faktore soos waardes en voordele wat die verbruiker in die aankoopproses as belangrik beskou.

\section{Doel en omvang van studie}

By die aankoop van ' $n$ motor is daar verskeie evalueringskriteria wat 'n koper in ag neem. Die doel van hierdie studie is om te bepaal of daar onderliggend aan die evalueringskriteria, 'n kleiner getal dimensies geïdentifiseer kan word, gegrond op die koper se persepsie van die relatiewe belangrikheid van die kriteria.

Die studie is beperk tot aankope van passasiersmotorvoertuie vir private gebruik; sluit nuwe sowel as gebruikte motors in; is uitgevoer in hoofsaaklik metropolitaanse gebiede van die RSA; en betrek kopers van alle rassegroepe.

\section{Kriteria by motoraankope aanwesig}

Vyf fases in die verbruiker se besluitnemingsproses kan geïdentifiseer word, naamlik: probleembewuswording, inligtingsoeke, alternatiefevaluering, koopaksie en resultaat (Engel, Blackwell \& Miniard, 1986:35).

Die alternatiefevalueringsfase word verder verdeel in verskeie elemente soos in Figuur 1 aangetoon.

Uit Figuur 1 kan gesien word dat evalueringskriteria die grondslag van die verbruiker se opvattings vorm en dit, tesame met houdings en voornemens het ' $n$ uitwerking op die alternatiefevaluering- en aankoopfase.

Engel, et al. (1986:93) omskryf evalueringskriteria as 


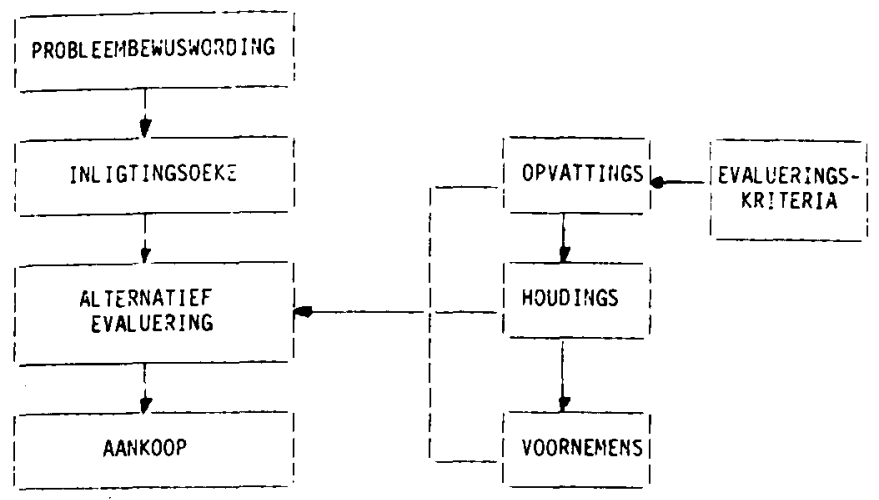

Figuur 1 Die alternatiefevalueringsfase van die verbruiker (Engel, et al., 1986).(Vertaal.)

produkgebaseerde voorstellings van onderliggende motiewe. Die belangrikste eienskappe van evalueringskriteria is die aantal kriteria wat gebruik word in die besluitnemingsproses, asook die relatiewe belangrikheid en opvallendheid ('salience') van elke kriterium. Oor laasgenoemde sê Engel, et al. (1986:96): 'Salience refers to the potential influence each criterion may exert during the comparison process and is often measured in terms of importance.' Dit kan, uiteraard, gebeur dat 'n opvallende evalueringskriterium geen invloed op die evalueringsproses het nie. ' $n$ Voorbeeld hiervan is waar die prys van alternatiewe dieselfde is en gevolglik vorm hierdie kriterium dan nie verder deel van die evalueringsproses nie. Die aantal evalueringskriteria wat in besluitneming gebruik word is, in die algemeen, ses of minder, alhoewel Fishbein (in Engel, et al. 1982:95) suggereer dat die aantal tot soveel as nege kan wees.

Evalueringskriteria kan in die vorm van fisiese produkattribute uitgedruk word en/of dit kan subjektiewe faktore soos waardes en voordele wees wat die verbruiker as belangrik in die aankoopbesluit beskou. Die sogenaamde voordelesegmentasie-konsep word deur bemarkers gebruik om markte volgens die voordele wat verbruikers verlang, te segmenteer. Hierdie evalueringskriteria, in terme van voordele, kan byvoorbeeld gebruik word om die teikenmark verder te verfyn volgens situasies en demografiese veranderlikes (Dickson 1982: 56-64).

Die belangrikste oorsprong van evalueringskriteria is volgens Cohen (1981:373) waardes, motiewe, inligting en ervaring. Sekere inligting word in 'n persoon se langtermyngeheue geberg en word aan faktore soos vorige ervaring, gesinvoorkeure, persoonlike kommunikasie en reklame ontleen. Waar hierdie studie, onder andere, oor die relatiewe belangrikheid van evalueringskriteria by die aankoop van 'n motorvoertuig handel, word vervolgens na 'n aantal relevante empiriese ondersoeke gekyk.

Bullock (1961:114) het in 'n studie oor Negers en Blankes in die VSA bevind dat die prestigebeeld van motors weinig betekenis vir die deursnee bevolking het, en nie met verkoopstegnieke vooropgestel moet word nie.

Robertson, Zielinski \& Ward (1984:14) bespiegel dat dit rasioneel vir 'n verbruiker sal wees om 'n statusmotor te koop indien dit belangrik vir die verbruiker se selfkonsep is om 'n hoë-aansienmotor te besit.

Die belangrikste eienskappe (kriteria) in motorkeuse wat deur Rousseau (1977:175-183) vasgestel is by kopers in Suid-Afrika was padhouvermoë, werkverrigting, rygerief en prys.

Stewart \& Hood (1981a, 1981b) het bevind dat die belangrikste attribute vir potensiële kopers van nuwe motors prys, betroubaarheid en ruimheid was.

South African Associated Newspapers (SAAN) het in 1981, 1982 en 1984 gesindikeerde navorsing in SuidAfrika oor kopers van nuwe motors laat uitvoer. Respondente is, onder andere, gevra om 30 eienskappe (kriteria) volgens die belangrikheid daarvan te evalueer by die keuse van 'n motor (Newsdesk 1982, 1983, 1984). Die attribute wat deur kopers as die belangrikste beskou is, word in Tabel 1 aangedui.

Tabel 1 Evaluering van attribute wat deur kopers as die belangrikste beskou word by die aankoop van 'n nuwe motor

\begin{tabular}{|c|c|c|}
\hline $\begin{array}{c}1981 \\
\text { Attribute (in } \\
\text { rangorde van } \\
\text { belangrikheid) }\end{array}$ & $\begin{array}{c}1982 \\
\text { Attribute (in } \\
\text { rangorde van } \\
\text { belangrikheid) }\end{array}$ & $\begin{array}{c}1984 \\
\text { Attribute (in } \\
\text { rangorde van } \\
\text { belangrikheid }\end{array}$ \\
\hline Betroubaarheid & Betroubaarheid & Betroubaarheid \\
\hline Padhouvermoë & Padhouvermoë & Padhouvermoë \\
\hline Werkverrigting & $\begin{array}{l}\text { Brandstofdoeltref- } \\
\text { fendheid }\end{array}$ & Werkverrigting \\
\hline $\begin{array}{l}\text { Brandstofdoel- } \\
\text { treffendheid }\end{array}$ & Werkverrigting & $\begin{array}{l}\text { Gehalte van } \\
\text { vakmanskap }\end{array}$ \\
\hline $\begin{array}{l}\text { Gehalte van } \\
\text { vakmanskap }\end{array}$ & $\begin{array}{l}\text { Gehalte van } \\
\text { vakmanskap }\end{array}$ & $\begin{array}{l}\text { Binneruimte } \\
\text { gemak }\end{array}$ \\
\hline $\begin{array}{l}\text { Binneruimte } \\
\text { gemak }\end{array}$ & Afwerkingsgehalte & $\begin{array}{l}\text { Brandstofdoeltref- } \\
\text { fendheid }\end{array}$ \\
\hline $\begin{array}{l}\text { Stilering/ } \\
\text { voorkoms }\end{array}$ & $\begin{array}{l}\text { Binneruimte } \\
\text { gemak }\end{array}$ & $\begin{array}{l}\text { Stilering/ } \\
\text { voorkoms }\end{array}$ \\
\hline $\begin{array}{l}\text { Vervaardiger } \\
\text { se reputasie }\end{array}$ & $\begin{array}{l}\text { Stilering/ } \\
\text { voorkoms }\end{array}$ & Afwerkingsgehalte \\
\hline $\begin{array}{l}\text { Afwerkingsge- } \\
\text { halte }\end{array}$ & Veiligheidsaspekte & Veiligheidsaspekte \\
\hline Aankoopprys & $\begin{array}{l}\text { Vervaardiger se } \\
\text { reputasie }\end{array}$ & $\begin{array}{l}\text { Vervaardiger se } \\
\text { reputasie }\end{array}$ \\
\hline Newsdesk (1982) & Newsdesk (1983) & Newsdesk (1984) \\
\hline
\end{tabular}

Tussen 1981 en 1982 het brandstofdoeltreffendheid, gehalte van afwerking en veiligheidsaspekte in belangrikheid toegeneem. Die prysattribuut word nie aangetoon nie, maar beklee die 11de plek. Afrikaanssprekendes het brandstofdoeltreffendheid as die derde belangrikste attribuut beskou en vir Engelsprekendes was dit die sesde belangrikste attribuut

'n Vergelyking tussen 1982 en 1984, toon aan dat binneruimte-gemak effens belangriker in die ondersoek van 1984 geword het. Brandstofdoeltreffendheid skyn asof dit nie meer so 'n belangrike faktor in 1984 as in 1982 en 1981 was nie. 
Binne die grootteklas van motors kọm daar uiteraard ook verskille tevoorskyn. Die twee belangrikste faktore vir kopers van alle grootte motors bly betroubaarheid en padhouvermoë, maar die derde belangrikste faktor verander na brandstofdoeltreffendheid in die geval van klein motors, binneruimte-gemak in die geval van middelslagmotors en gehalte van vakmanskap in die geval van groot motors. Werkverrigting is die vierde belangrikste attribuut vir klein- en middelslagmotorkopers en in die geval van groot motors is dit binneruimtegemak. Die vyfde posisie word deur gehalte van vakmanskap vir klein- en middelslagmotorkopers beklee en vir groot motors is dit werkverrigting.

Vir die doeleindes van hierdie studie word produkattribute in die konteks van die belangrikheid daarvan vir die verbruiker gebruik, soos deur hom waargeneem, en nie vanuit 'n objektiewe vlak van belangrikheid, intrinsiek in die produk nie (Bloch \& Richins 1983:69).

Vyf en sestig kriteria wat deur 'n koper oorweeg word

Tabel 2 Evalueringskriteria by die aankoop van 'n motorvoertuig vir privaatgebruik

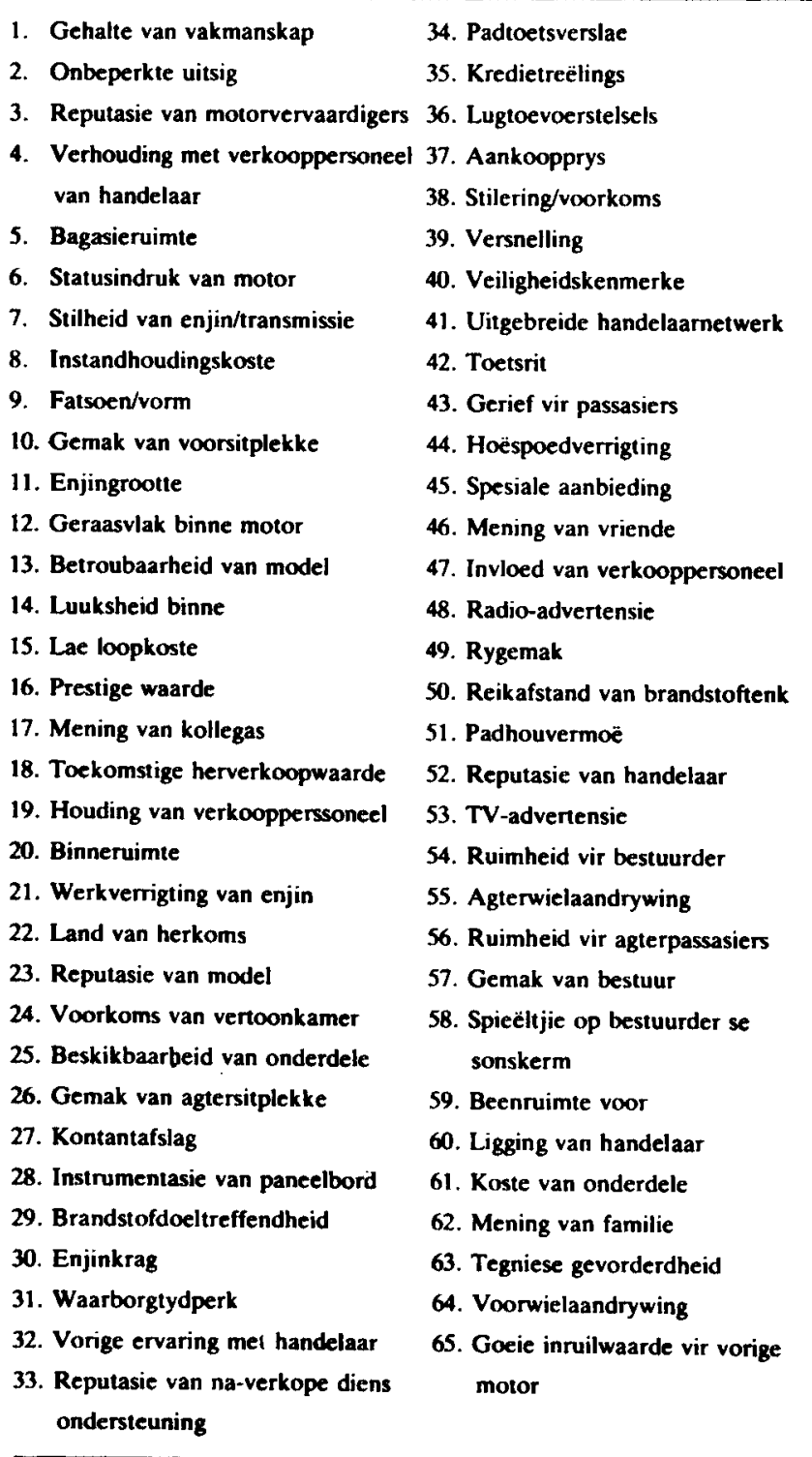

by die aankoop van 'n motor, word in hierdie studie gebruik om te bepaal watter relatiewe belangrikheid aan evalueringskriteria geheg word. Hierdie kriteria verskyn in Tabel 2.

Hierdie studie word van vorige navorsing onderskei deurdat dit alle rassegroepe in die RSA insluit en dat dit van 'n meerveranderlike statistiese tegniek naamlik faktorontleding, gebruik maak om die groot getal evalueringskriteria sinryk tot 'n kleiner getal dimensies te reduseer.

\section{Probleemformulering}

Die probleem van hierdie studie het betrekking op die vraag of daar onderliggend aan die groot getal evalueringskriteria in Tabel 2, 'n kleiner getal dimensies of faktore geïdentifiseer kan word gegrond op die koper se persepsie van die relatiewe belangrikheid daarvan by die aankoop van 'n motor.

\section{Navorsingsontwerp en -ontleding}

Die steekproef het bestaan uit 902 verbruikers van hoofsaaklik metropolitaanse gebiede in Suid-Afrika, wat tussen Desember 1985 en Mei 1986 'n nuwe of gebruikte motor vir privaatgebruik gekoop het. Die geografiese verspreiding van die verbruikersteekproef word in Tabel 3 aangetoon.

Tabel 3 Geografiese verspreiding van verbruikersteekproef oor die Republiek van Suid-Afrika

\begin{tabular}{lrr}
\hline Gebied & Aantal & $\%$ \\
\hline Pretoria/Verwoerdburg & 184 & 20,4 \\
Johannesburg & 178 & 19,7 \\
Oos-Rand en Wes-Rand & 99 & 11,0 \\
Vereeniging/Vanderbijlpark & 52 & 5,8 \\
Subtotaal PWV-gebied & 513 & 56,9 \\
Durban/Pinetown & 170 & 18,8 \\
Kaapstad & 185 & 20,5 \\
Noord-Transvaal & 34 & 3,8 \\
Totaal & 902 & 100,0 \\
\hline
\end{tabular}

Binne hierdie geografiese gebiede in Tabel 3 is motorhandelaars vooraf geïdentifiseer om ' $n$ verteenwoordigende verdeling van die onderskeie motorvervaardigers in die steekproef op te neem. Vir ' $n$ volledige bespreking van die steekproefmetode en meetinstrument word verwys na Du Plessis (1986:164-190).

Die demografiese eienskappe van respondente in die steekproef verskyn in Tabel 4.

Die metode van data-insameling wat gevolg is het bestaan uit 'n gestruktureerde vraelys wat kopers by die motorhandelaar moes voltooi nadat ' $n$ motor gekoop is. Evalueringskriteria (in Tabel 2) het die belangrikste komponent van die vraelys verteenwoordig. Responsies op elke kriterium word op 'n skaal van een tot ses aangeslaan. Die skaalwaarde van een dui aan dat die kriterium 
Tabel 4 Demografiese eienskappe van respondente in die steekproef

\begin{tabular}{|c|c|c|c|c|c|c|c|c|c|c|}
\hline \multirow[b]{3}{*}{ Klassifikasie } & \multicolumn{10}{|c|}{ Rassegroep } \\
\hline & \multicolumn{2}{|r|}{ Blankes } & \multicolumn{2}{|r|}{ Kleurlinge } & \multicolumn{2}{|r|}{ Asiërs } & \multicolumn{2}{|r|}{ Swartes } & \multicolumn{2}{|c|}{ Totaal } \\
\hline & $\begin{array}{c}\text { Aan- } \\
\text { tal }\end{array}$ & $\begin{array}{c}\% \text { van Blankes } \\
\text { se totaal }\end{array}$ & $\begin{array}{c}\text { Aan- } \\
\text { tal }\end{array}$ & $\begin{array}{l}\% \text { van Kleur- } \\
\text { linge se totaal }\end{array}$ & $\begin{array}{c}\text { Aan- } \\
\text { tal }\end{array}$ & $\begin{array}{c}\% \text { van Asiërs } \\
\text { se totaal }\end{array}$ & $\begin{array}{c}\text { Aan- } \\
\text { tal }\end{array}$ & $\begin{array}{c}\% \text { van Swartes } \\
\text { se totaal }\end{array}$ & $\begin{array}{c}\text { Aan- } \\
\text { tal }\end{array}$ & $\%$ \\
\hline \multicolumn{11}{|l|}{ 1. Geslag } \\
\hline Manlik & 451 & 78,2 & 95 & 83,3 & 97 & 95,1 & 93 & 85,3 & 736 & 81,6 \\
\hline Vroulik & 126 & 21,8 & 19 & 16,7 & 5 & 4,9 & 16 & 14,7 & 166 & 18,4 \\
\hline \multicolumn{11}{|l|}{ 2. Huistaal } \\
\hline Afrikaans & 251 & 43,5 & 57 & 50,0 & - & - & 4 & 3,7 & 312 & 34,6 \\
\hline Engels & 311 & 53,9 & 57 & 50,0 & 93 & 91,2 & 18 & 16,5 & 479 & 53,1 \\
\hline Ander & 15 & 2,6 & - & - & 9 & 8,8 & 87 & 79,8 & 111 & 12,3 \\
\hline \multicolumn{11}{|l|}{ 3. Onderwyspeil ${ }^{a}$} \\
\hline St 6 & 2 & 0,3 & 4 & 3,5 & 5 & 4,9 & 5 & 4,6 & 16 & 1,8 \\
\hline St 8 & 34 & 5,9 & 28 & 24,6 & 21 & 20,6 & 31 & 18,4 & 114 & 12,6 \\
\hline Matriek & 203 & 35,2 & 48 & 42,1 & 47 & 46,1 & 48 & 44,0 & 346 & 38,4 \\
\hline Naskoolse diploma & 157 & 27,3 & 22 & 19,3 & 11 & 10,8 & 15 & 13,8 & 205 & 22,7 \\
\hline Universitcitsgraad & 181 & 31,3 & 12 & 10,5 & 18 & 17,6 & 10 & 9,2 & 221 & 24,5 \\
\hline \multicolumn{11}{|l|}{ 4. Beroepsgroep } \\
\hline Polisie/weermag & 12 & 2,1 & 7 & 6,1 & 9 & 8,8 & 1 & 0,9 & 29 & 3,2 \\
\hline Klerklik/verkope & 122 & 21,1 & 29 & 25,4 & 41 & $\mathbf{4 0 , 2}$ & 30 & 27,6 & 222 & 24,6 \\
\hline Professioneel & 153 & 26,5 & 32 & 28,1 & 18 & $\cdot 17,6$ & 25 & 22,9 & 228 & 25,3 \\
\hline Vakman/geskoolde werker & 44 & 7,6 & 16 & 14,0 & 10 & 9,8 & 7 & 6,4 & 77 & 8,5 \\
\hline Eie besigheid & 40 & 6,9 & 9 & 7,9 & 10 & 9,8 & 26 & 23,9 & 85 & 9,4 \\
\hline Huisvrou/tuisteskepper & 8 & 1,4 & 2 & 1,8 & - & - & 2 & 1,8 & 12 & 1,3 \\
\hline Ongeskoolde werker & - & - & 1 & 0,9 & - & - & 3 & 2,8 & 4 & 0,4 \\
\hline Student & 5 & 0,9 & 5 & 4,4 & 1 & 1,0 & 2 & 1,8 & 13 & 1,4 \\
\hline Bestuur/uitvoerend & 161 & 27,9 & 7 & 6,1 & 10 & 9,8 & 6 & 5,5 & 184 & 20,4 \\
\hline Fabriekswerker & 7 & 1,2 & 3 & 2,6 & 2 & 2.0 & 3 & 2,8 & 15 & 1,7 \\
\hline Afgetree & 12 & 2,1 & 2 & 1,8 & 1 & 1,0 & 2 & 1,8 & 17 & 1,9 \\
\hline Werkloos & 1 & 0,2 & 1 & 0,9 & - & - & - & - & 2 & 0,2 \\
\hline $\begin{array}{l}\text { Ander (bv. vlieënier, } \\
\text { diplomaat, lugwaardin) }\end{array}$ & 12 & 2,1 & - & - & - & - & 2 & 1,8 & 14 & 1,6 \\
\hline \multicolumn{11}{|l|}{ 5. Ouderdom } \\
\hline $18-24$ & 42 & 7,3 & 16 & 14,0 & 15 & 14,7 & 1 & 0,9 & 74 & 8,2 \\
\hline $25-30$ & 97 & $\cdot 16,8$ & 32 & 28,1 & 27 & 26,5 & 15 & 13,8 & 171 & 19,0 \\
\hline $31-35$ & 111 & 19,2 & 21 & 18,4 & 21 & 20,6 & 24 & 22,0 & 177 & 19,6 \\
\hline $36-45$ & 177 & 30,7 & 26 & 22,8 & 28 & 27,5 & 41 & 37,6 & 272 & 30,2 \\
\hline $46-55$ & 109 & 18,9 & 17 & 14,9 & 8 & 7,8 & 25 & 22,9 & 159 & 17,6 \\
\hline $56-64$ & 32 & 5,5 & 2 & 1,8 & 3 & 2,9 & 3 & 2,8 & 40 & 4,4 \\
\hline $65+$ & 9 & 1,6 & - & - & - & - & - & - & 9 & 1,0 \\
\hline \multicolumn{11}{|l|}{ 6. Huwelikstatus } \\
\hline Huidig getroud & 435 & 75,4 & 74 & 64,9 & 72 & 70,6 & 79 & 72,5 & 660 & 73,2 \\
\hline Geskei & 52 & 9,0 & 4 & 3,5 & 1 & 1,0 & 4 & 3,6 & 61 & 6,7 \\
\hline Nooit getroud & 79 & 13,7 & 34 & 29,8 & 28 & 27,4 & 23 & 21,1 & 164 & 18,2 \\
\hline Wedustaat & 11 & 1,9 & 2 & 1,8 & 1 & 1,0 & 3 & 2,8 & 17 & 1,9 \\
\hline \multicolumn{11}{|c|}{ 7. Bruto huishoudelike maandelikse inkomste } \\
\hline$<\mathrm{R} 600$ & 6 & 1,0 & 6 & 5,3 & 6 & 5,9 & 9 & 8,3 & 27 & 3,0 \\
\hline$R 600-R 999$ & 21 & 3,6 & 19 & 16,7 & 25 & 24,5 & 24 & 22,0 & 89 & 9,9 \\
\hline R1000-R1499 & 43 & 7,5 & 25 & 21,8 & 23 & 22,5 & 27 & 24,8 & 118 & 13,1 \\
\hline R1500-R1999 & 75 & 13,0 & 22 & 19,3 & 22 & 21,6 & 16 & 14,7 & 135 & 15,0 \\
\hline R2000-R2999 & 174 & 30,2 & 22 & 19,3 & 13 & 12,7 & 14 & 12,8 & 223 & 24,7 \\
\hline R3000-R3999 & 147 & 25,5 & 10 & 8,8 & 4 & 3,9 & 11 & 10,1 & 172 & 219.1 \\
\hline \multirow[t]{2}{*}{$\mathbf{R} 4000+$} & 111 & 19,2 & 10 & 8,8 & 9 & 8,8 & 8 & 7,3 & 138 & $\begin{array}{l}815,3 \\
\end{array}$ \\
\hline & \multicolumn{2}{|r|}{$n=577$} & \multicolumn{2}{|r|}{$n=114$} & \multicolumn{2}{|r|}{$n=102$} & & $n=109$ & & $=902$ \\
\hline
\end{tabular}

\footnotetext{
a Hoogste vlak
} 
vir die respondent totaal onbelangrik was by die keuse van die betrokke motor, terwyl die sesde waarde uiters belangrikheid vir die verbruiker aantoon. Die skaalwaardes kan gedefinieer word as diskrete posisies op 'n veronderstelde kontinium van belangrikheid vir die respondent (Boote 1981:54).

Argumente oor die optimum aantal responsiealternatiewe vir 'n skaal bestaan sedert die eerste gebruik van sodanige meetinstrument (Cox 1980:407). $\mathrm{Na}$ 'n omvattende literatuurstudie het $\mathrm{Cox}(1980: 420)$ tot die gevolgtrekking gekom dat skale met twee of drie responsie-alternatiewe, in die algemeen, onvoldoende is aangesien dit nie genoegsame inligting oordra nie en dat dit respondente frustreer en onderdruk. Verder is bevind dat die marginale voordeel om meer as nege responsie-alternatiewe te gebruik, minimaal is. Die optimum aantal responsie-alternatiewe lê tussen vyf en nege. In die onderhawige geval waar ' $n$ responsie geposisioneer word op ' $n$ kontinuum van enkelattribute is vyf responsie-alternatiewe voldoende (Cox 1980:420). 'n Onewe getal responsie-alternatiewe is verkieslik waar die respondent regmatig ' $n$ neutrale posisie kan inneem. Die kriteria in hierdie vraelys leen hulself nie tot ' $n$ onsydige keuse nie en ses responsie-alternatiewe is derhalwe beskou as ' $n$ aanvaarbare aantal om die kriteria te meet. Die ewegetal sal ook bydra om die moontlikheid van 'n sentrale geneigdheidsfout uit te skakel (Huysamen 1983:111). Alhoewel die aantal responsiealternatiewe nie absoluut krities in hierdie studie is nie, is die gebruik van ses responsie-alternatiewe verdedigbaar. Nunnally (1967:522) meld ook dat daar in die meeste gevalle 'n geringe voordeel is om 'n ewegetal responsie-alternatiewe te gebruik en illustreer dit met behulp van 'n sesstapskaalvoorbeeld. Wat geldigheid betref verklaar Nunnally (1967:521) dat daar 'n afplatting by sewe stappe begin intree en na 11 stappe is daar min verhoging in geldigheid te verkry.

Soos bekend, is faktorontledingstegnieke ontwikkel om inligting oor die onderliggende struktuur van 'n versameling veranderlikes te verkry. In effek word daar gepostuleer dat die variansie wat met elke itemtelling geassosieer word, saamgestel word uit die variansie wat die item gemeenskaplik het met ander items en die variansie wat uniek is aan die item self.

Wanneer daar min kennis oor die onderliggende struktuur van die data bestaan, kan die data aan eksploratiewe faktorontledingsprosedures onderwerp word. Sodanige prosedures maak gebruik van 'n verskeidenheid metodes om die aantal onderliggende faktore te bepaal (Mulaik, 1972). Daarna kan 'n rotasiemetode gebruik word om die betekenis van die verkreë ontleding te optimiseer. Die spesifisering van 'n rotasie is noodsaaklik aangesien die faktorontledingsmodel invariant is onder ortogonale rotasie.

Om uit die evalueringskriteria van die verbruikers onderliggende dimensies te bepaal, is daar van 'n hooffaktorontleding met die meegaande 'varimax'-rotasie gebruik gemaak. Die faktorontledings is uitgevoer op korrelasiematrikse met ene, as anvanklike skattings van die kommunaliteite, in die diagonaal. Tien iterasies word gespesifiseer, maar die iterasieproses kom tot 'n einde voordat hierdie gespesifiseerde getal bereik is, indien die verandering in kommunaliteitskattings kleiner as 0,001 is. Kaiser (1958) se kriterium vir die getal faktore wat geïdentifiseer is, is gebruik.

\section{Resultate en Interpretasie}

Die gemiddelde standaardafwykings en interkorrelasiematriks van die evalueringskriteria verskyn in Du Plessis (1986). Nadat die faktormatriks aan Kaiser (1958) se 'varimax'-rotasiemetode onderwerp is, is 12 faktore uit die interkorrelasies van die 65 evalueringskriteria geïsoleer. Die geroteerde faktormatriks verskyn in Tabel 5.

Hierdie faktore verklaar $59,82 \%^{1}$ van die totale variansie onder al die evalueringskriteria.

Tabel 5 Geroteerde faktormatriks en verspreiding van kommunaliteite $\left(h^{2}\right)$ vir evalueringskriteria volgens verbruikers (alle rassegroepe)

\begin{tabular}{|c|c|c|c|c|c|c|c|c|c|c|c|c|c|c|}
\hline \multirow{2}{*}{$\begin{array}{l}\text { Kriterium } \\
\text { nommer }\end{array}$} & \multirow{2}{*}{$\begin{array}{c}\text { Beskrywing van } \\
\text { evalueringskriterium }\end{array}$} & \multicolumn{12}{|c|}{ Faktore } & \multirow{2}{*}{$\begin{array}{l}\text { Kom- } \\
\text { munali- } \\
- \text { teite } \\
\left(h^{2}\right)\end{array}$} \\
\hline & & 1 & 2 & 3 & 4 & 5 & 6 & 7 & 8 & 9 & 10 & 11 & 12 & \\
\hline 1. & Gehalte van vakmanskap & 0,188 & 0,146 & 0,178 & 0,174 & 0,294 & 0,114 & $-0,033$ & 0,513 & $-0,107$ & 0,041 & $-0,095$ & 0,085 & 0,516 \\
\hline 2. & Onbeperkte uitsig & 0,323 & 0,173 & 0,186 & 0,192 & 0,105 & 0,090 & $-0,076$ & 0,512 & 0,117 & 0,104 & $-0,017$ & 0,122 & 0,576 \\
\hline 3. & $\begin{array}{l}\text { Reputasie van motorver- } \\
\text { vaardigers }\end{array}$ & 0,250 & 0,071 & 0,029 & 0,117 & 0,025 & 0,086 & 0,098 & 0,659 & 0,062 & $-0,013$ & 0,062 & 0,013 & 0,647 \\
\hline 4. & $\begin{array}{l}\text { Verhouding met verkoop- } \\
\text { personeel van die hande- } \\
\text { laar }\end{array}$ & 0,686 & 0,072 & 0,079 & $-0,045$ & $-0,040$ & 0,180 & 0,025 & 0,252 & 0,116 & 0,071 & 0,202 & 0,106 & 0,653 \\
\hline 5. & Bagasieruimte & 0,102 & 0,115 & 0,451 & 0,137 & $-0,111$ & 0,243 & $-0,045$ & 0,320 & 0,139 & 0,184 & 0,119 & 0,144 & 0,514 \\
\hline 6. & Statusindiuk van motor & 0,174 & 0,016 & 0,178 & 0,054 & 0,222 & 0,597 & 0,323 & 0,113 & 0,118 & $-0,035$ & 0,204 & $-0,057$ & 0,650 \\
\hline 7. & $\begin{array}{l}\text { Stilheid van enjin/trans- } \\
\text { missie }\end{array}$ & 0,113 & 0,283 & 0,395 & 0,186 & 0,181 & 0,300 & 0,093 & 0,261 & 0,100 & $-0,006$ & 0,303 & $-0,029$ & 0,593 \\
\hline 8. & Instandhoudingskoste & 0,124 & 0,770 & 0,093 & 0,014 & 0,015 & 0,086 & $-0,069$ & 0,111 & 0,017 & 0,170 & 0,017 & 0,015 & 0,672 \\
\hline
\end{tabular}




\begin{tabular}{|c|c|c|c|c|c|c|c|c|c|c|c|c|c|c|}
\hline \multirow{2}{*}{$\begin{array}{l}\text { Kriterium } \\
\text { nommer }\end{array}$} & \multirow{2}{*}{$\begin{array}{c}\text { Beskrywing van } \\
\text { evalueringskriterium }\end{array}$} & \multicolumn{12}{|c|}{ Faktore } & \multirow{2}{*}{$\begin{array}{c}\text { Kom- } \\
\text { munali- } \\
-\quad \text { teite } \\
\left(h^{2}\right)\end{array}$} \\
\hline & & 1 & 2 & 3 & 4 & 5 & 6 & 7 & 8 & 9 & 10 & 11 & 12 & \\
\hline$\overline{9}$. & Fatsoen/vorm & 0,075 & 0,021 & 0,081 & 0,137 & 0,090 & 0,753 & 0,054 & 0,074 & 0,038 & 0,156 & $-0,009$ & 0,092 & 0,662 \\
\hline 10. & Gemak van voorsitplekke & 0,129 & 0,157 & 0,296 & 0,429 & 0,160 & 0,412 & $-0,017$ & 0,312 & 0,052 & $-0,028$ & 0,062 & 0,010 & 0,618 \\
\hline 11. & Enjingrootte & 0,125 & $-0,045$ & 0,210 & 0,014 & 0,365 & 0,269 & $-0,064$ & 0,150 & $-0,164$ & 0,203 & 0,186 & 0,282 & 0,564 \\
\hline 12. & Geraasvlak binne motor & 0,150 & 0,226 & 0,435 & 0,188 & 0,294 & 0,295 & $-0,005$ & 0,193 & $-0,153$ & 0,032 & 0,120 & 0,097 & 0,557 \\
\hline 13. & $\begin{array}{l}\text { Betroubaarheid van dié } \\
\text { model }\end{array}$ & 0,094 & 0,497 & 0,046 & 0,276 & 0,119 & 0,119 & $-0,001$ & 0,427 & $-0,056$ & $-0,074$ & $-0,002$ & $-0,110$ & 0,615 \\
\hline 14. & Luuksheid binne & 0,096 & 0,023 & 0,254 & 0,332 & 0,283 & 0,510 & 0,205 & 0,122 & 0,013 & 0,017 & 0,067 & 0,065 & 0,592 \\
\hline 15. & Lae loopkoste & 0,076 & 0,782 & 0,134 & $-0,009$ & 0,047 & 0,044 & 0,126 & 0,080 & $-0,024$ & $-0,039$ & $-0,160$ & $-0,007$ & 0,690 \\
\hline 16. & Prestige waarde & 0,148 & 0,110 & 0,097 & 0,109 & 0,175 & 0,564 & 0,382 & 0,053 & 0,208 & 0,001 & 0,255 & $-0,105$ & 0,677 \\
\hline 17. & Mening van kollegas & 0,053 & 0,007 & 0,015 & $-0,101$ & 0,077 & 0,153 & 0,747 & 0,083 & $-0,005$ & 0,078 & 0,173 & 0,140 & 0,654 \\
\hline 18. & $\begin{array}{l}\text { Toekomstige herverkoop- } \\
\text { waarde }\end{array}$ & 0,276 & 0,420 & 0,163 & 0,140 & 0,110 & 0,278 & 0,037 & $-0,043$ & 0,121 & $-0,116$ & 0,248 & $-0,029$ & 0,518 \\
\hline 19. & $\begin{array}{l}\text { Houding van verkoopper- } \\
\text { soneel }\end{array}$ & 0,730 & 0,112 & 0,079 & 0,061 & 0,067 & 0,130 & 0,089 & 0,139 & 0,025 & $-0,020$ & $-0,013$ & 0,013 & 0,610 \\
\hline 20. & Binneruimte & 0,168 & 0,108 & 0,584 & 0,237 & 0,042 & 0,242 & $-0,032$ & 0,211 & 0,105 & 0,054 & 0,050 & 0,102 & 0,572 \\
\hline 21. & Werkverrigting van enjin & 0,045 & 0,346 & 0,028 & 0,197 & 0,489 & 0,198 & $-0,042$ & 0,213 & 0,272 & 0,033 & 0,253 & 0,010 & 0,626 \\
\hline 22. & Land van herkoms & 0,251 & 0,033 & 0,101 & $-0,031$ & 0,196 & 0,252 & 0,172 & 0,059 & 0,111 & 0,405 & 0,057 & $-0,025$ & 0,473 \\
\hline 23. & Reputasie van model & 0,204 & 0,190 & 0,133 & 0,057 & 0,134 & 0,229 & 0,038 & 0,172 & 0,063 & 0,011 & $-0,074$ & 0,015 & 0,643 \\
\hline 24. & $\begin{array}{l}\text { Voorkoms van vertoon- } \\
\text { lokaal }\end{array}$ & 0,607 & 0,064 & 0,200 & $-0,014$ & 0,164 & 0,169 & 0,245 & 0,029 & 0,015 & 0,174 & $-0,120$ & $-0,001$ & 0,575 \\
\hline 25. & $\begin{array}{l}\text { Beskikbaarheid van onder- } \\
\text { dele }\end{array}$ & 0,253 & 0,598 & 0,140 & 0,200 & 0,104 & 0,016 & $-0,050$ & 0,130 & 0,170 & $-0,005$ & 0,167 & 0,036 & 0,571 \\
\hline 26. & Gemak van agtersitplekke & 0,145 & 0,161 & 0,727 & 0,117 & 0,079 & 0,102 & 0,106 & $-0,003$ & 0,089 & 0,208 & 0,129 & 0,044 & 0,711 \\
\hline 27. & Kontantafslag & 0,067 & 0,094 & $-0,045$ & $-0,042$ & 0,024 & 0,041 & 0,260 & 0,081 & 0,055 & $-0,024$ & 0,001 & 0,669 & 0,546 \\
\hline 28. & $\begin{array}{l}\text { Instrumentasie van paneel- } \\
\text { bord }\end{array}$ & 0,157 & 0,100 & 0,278 & 0,254 & 0,345 & 0,291 & 0,101 & 0,114 & $-0,032$ & 0,089 & $-0,007$ & 0,356 & 0,539 \\
\hline 29. & Brandstofdoeltreffendheid & 0,093 & 0,729 & 0,120 & 0,142 & 0,056 & 0,025 & 0,053 & 0,027 & 0,123 & 0,141 & $-0,005$ & 0,165 & 0,647 \\
\hline 30. & Enjinkrag & 0,039 & 0,195 & 0,099 & 0,184 & 0,525 & 0,274 & 0,033 & 0,086 & 0,235 & 0,170 & 0,389 & 0,155 & 0,703 \\
\hline 31. & Waarborgtydperk & 0,346 & 0,386 & 0,090 & 0,137 & 0,167 & 0,016 & $-0,044$ & $-0,029$ & 0,358 & 0,102 & 0,240 & 0,302 & 0,619 \\
\hline 32. & $\begin{array}{l}\text { Vorige ervaring met } \\
\text { handelaar }\end{array}$ & 0,613 & 0,127 & 0,119 & 0,123 & 0,025 & 0,122 & 0,066 & 0,035 & 0,130 & 0,113 & 0,218 & 0,080 & 0,533 \\
\hline 33. & $\begin{array}{l}\text { Reputasie van na-verkope } \\
\text { diens ondersteuning }\end{array}$ & 0,629 & 0,221 & 0,115 & 0,192 & 0,254 & $-0,085$ & 0,103 & 0,087 & 0,019 & $-0,072$ & $-0,024$ & 0,080 & 0,614 \\
\hline 34. & Padtoetsverslae & 0,146 & 0,181 & 74 & 0,147 & 0,190 & 0,083 & 0,193 & 0,129 & 0,505 & 0,189 & 0,124 & $-0,069$ & 0,551 \\
\hline 35. & Kredietreëlings & 0,174 & 0,268 & 0,061 & $-0,042$ & 0,257 & 0,026 & 0,361 & $-0,011$ & 0,139 & 0,111 & $-0,087$ & 0,057 & 0,418 \\
\hline 36. & Lugtoevoerstelsel & 0,139 & 0,178 & 0,312 & 0,275 & 0,380 & 0,150 & 0,050 & 0,080 & $-0,061$ & 0,105 & $-0,116$ & 0,228 & 0,480 \\
\hline 37. & Aankoopprys & 0,017 & 0,399 & 0,108 & 0,064 & 0,094 & $-0,017$ & 0,047 & $-0,057$ & 0,307 & 0,014 & $-0,369$ & 0,441 & 0,650 \\
\hline 38. & Stilering/voorkoms & 0,098 & 0,075 & 0,066 & 0,160 & 0,257 & 0,637 & 0,095 & $-0,038$ & 0,069 & 0,134 & $-0,275$ & 0,073 & 0,673 \\
\hline 39. & Versnelling & 0,107 & 0,039 & 0,139 & 0,131 & 0,662 & 0,280 & 0,122 & 0,008 & 0,089 & 0,198 & 0,017 & 0,131 & 0,684 \\
\hline 40. & Veiligheidskenmerke & 0,154 & 0,298 & 0,371 & 0,261 & 0,374 & 0,059 & 0,009 & 0,106 & 0,141 & $-0,076$ & $-0,009$ & 0,004 & 0,505 \\
\hline 41. & $\begin{array}{l}\text { Uitgebreide handelaarnet- } \\
\text { werk }\end{array}$ & 0,451 & 0,213 & 0,285 & 0,118 & 0,117 & $-0,064$ & 0,136 & 0,220 & 0,180 & 0,100 & $-0,065$ & $-0,026$ & 0,494 \\
\hline 42. & Toetsrit & 0,198 & 0,107 & 0,247 & 0,138 & 0,153 & 0,178 & 0,128 & 0,118 & 0,665 & 0,026 & 0,023 & $-0,026$ & 0,660 \\
\hline 43. & Gerief vir passasiers & 0,142 & 0,087 & 0,696 & 0,169 & 0,254 & 0,052 & 0,201 & 0,014 & 0,128 & 0,002 & $-0,191$ & $-0,129$ & 0,718 \\
\hline 44. & Hoëspoedverrigting & 0,081 & $-0,039$ & 0,128 & 0,105 & 0,709 & 0,206 & 0,139 & 0,025 & 0,185 & 0,109 & 0,046 & $-0,062$ & 0,653 \\
\hline 45. & Spesiale aanbieding & 0,187 & 0,187 & $-0,033$ & 0,024 & 0,067 & 0,064 & 0,239 & $-0,104$ & 0,588 & 0,142 & $-0,085$ & 0,176 & 0,560 \\
\hline 46. & Mening van vriende & 0,183 & $-0,050$ & 0,078 & 0,012 & 0,051 & 0,185 & 0,744 & 0,028 & 0,128 & 0,026 & $-0,084$ & 0,113 & 0,678 \\
\hline 47. & $\begin{array}{l}\text { Invloed van verkoopperso- } \\
\text { neel }\end{array}$ & 0,487 & 0,003 & $-0,030$ & $-0,001$ & $-0,015$ & 0,166 & 0,506 & 0,003 & 0,225 & 0,132 & 0,006 & $-0,070$ & 0,598 \\
\hline 48. & Radio-advertensie & 0,311 & 0,126 & 0,109 & 0,017 & 0,106 & 0,120 & 0,495 & $-0,047$ & 0,023 & 0,405 & $-0,055$ & $-0,046$ & 0,583 \\
\hline 49. & Rygemak & 0,123 & 0,102 & 0,337 & 0,519 & 0,342 & 0,173 & 0,079 & 0,145 & 0,150 & $-0,136$ & $-0,163$ & $-0,004$ & 0,667 \\
\hline 50. & $\begin{array}{l}\text { Reikafstand van brandstof- } \\
\text { tenk }\end{array}$ & 0,165 & 0,319 & 0,386 & 0,229 & 0,282 & 0,108 & 0,123 & 0,017 & 0,123 & 0,116 & 0,155 & 0,105 & 0,502 \\
\hline 5 & Padhouvermoë & 190 & 0,141 & 0,179 & 0,465 & 0,488 & $-0,014$ & 0,127 & 0,076 & $-0,063$ & $-0,110$ & $-0,172$ & $-0,095$ & 0,619 \\
\hline
\end{tabular}




\begin{tabular}{|c|c|c|c|c|c|c|c|c|c|c|c|c|c|c|}
\hline \multirow{2}{*}{$\begin{array}{l}\text { Kriterium } \\
\text { nommer }\end{array}$} & \multirow{2}{*}{$\begin{array}{c}\text { Beskrywing van } \\
\text { evalueringskriterium }\end{array}$} & \multicolumn{12}{|c|}{ Faktore } & \multirow{2}{*}{$\begin{array}{c}\text { Kom- } \\
\text { munali- } \\
\text { teite } \\
\left(h^{2}\right)^{\prime}\end{array}$} \\
\hline & & 1 & 2 & 3 & 4 & 5 & 6 & 7 & 8 & 9 & 10 & 11 & 12 & \\
\hline 52. & Reputasie van handelaar & 0,689 & 0,101 & 0,001 & 0,240 & 0.136 & $-0,011$ & 0,125 & 0,080 & 0,060 & 0,041 & $-0,088$ & $-0,029$ & 0,614 \\
\hline 53. & TV-advertensie & 0,358 & 0,143 & 0,115 & 0,030 & 0,032 & 0,205 & 0,281 & $-0,197$ & $-0,002$ & 0,444 & $-0,096$ & $-0,003$ & 0,530 \\
\hline 54. & Ruimheid vir bestuurder & 0,117 & 0,086 & 0,208 & 0,774 & 0,076 & 0,138 & $-0,012$ & 0.080 & 0,056 & $-0,010$ & 0,068 & 0,022 & 0,703 \\
\hline 55. & Agterwielaandrywing & 0,149 & 0,097 & 0,239 & 0,137 & 0.047 & 0,273 & $-0,080$ & $-0,006$ & 0,195 & 0,448 & $-0,030$ & 0,454 & \\
\hline 56. & $\begin{array}{l}\text { Ruimheid vir agterpassa- } \\
\text { siers }\end{array}$ & 0,045 & 0,126 & 0,691 & 0,299 & 0,134 & 0,016 & 0,186 & $-0,050$ & $-0,011$ & $-0,158$ & 0,079 & $-0,041$ & 0,697 \\
\hline 57. & Gemak van bestuur & 0,050 & 0,177 & 0,209 & 0,711 & 0,141 & 0,111 & $-0,008$ & 0,073 & 0,107 & 0,083 & 0,066 & 0,028 & 0,655 \\
\hline 58. & $\begin{array}{l}\text { Spieëltjie op bestuurder se } \\
\text { sonskerm }\end{array}$ & 0,128 & 0,072 & 0,268 & 0,064 & 0,145 & 0,029 & 0,260 & $-0,073$ & 0,058 & 0,503 & 0,059 & $-0,048$ & 0,486 \\
\hline 59. & Beenruimte voor & 0,169 & 0,124 & 0.154 & 0,773 & 0,065 & 0,164 & 0.038 & 0,072 & 0,090 & 0,144 & 0,051 & 0,025 & 0,737 \\
\hline 60. & Ligging van handelaar & 0,497 & 0,184 & 0,163 & 0,259 & $-0,084$ & 0,079 & 0,108 & 0,006 & 0,199 & 0,269 & 0,159 & 0,117 & 0,573 \\
\hline 61. & Koste van onderdele & 0,195 & 0,595 & 0,080 & 0,322 & 0,007 & $-0,089$ & 0,043 & $-0,102$ & 0,201 & 0,102 & 0,213 & 0,125 & 0,640 \\
\hline 62. & Mening van familie & 0,072 & $-0,002$ & 0,247 & 0,177 & 0,058 & $-0,043$ & 0,576 & $-0,092$ & 0,123 & 0,124 & 0,046 & 0,159 & 0,510 \\
\hline 63. & Tegniese gevorderdheid & 0,121 & 0,137 & 0,095 & 0,494 & 0,368 & 0,061 & 0,199 & 0,122 & $-0,047$ & 0,144 & 0,114 & $-0,023$ & 0,596 \\
\hline 64. & Voorwielaandrywing & 0,008 & 0,081 & 0,085 & 0,085 & 0.094 & 0,042 & 0,059 & 0,151 & 0,127 & 0,709 & 0,074 & 0,042 & 0,588 \\
\hline 65. & $\begin{array}{l}\text { Goeie inruilwaarde vir } \\
\text { vorige motor }\end{array}$ & 0,349 & 0,244 & 0,110 & 0,145 & 0,061 & 0,040 & 0,030 & $-0,289$ & $-0,117$ & $-0,144$ & 0,176 & 0,301 & 0,461 \\
\hline
\end{tabular}

Die verspreiding van die kommunaliteite $\left(h^{2}\right)$ word ook in Tabel 5 voorgestel. Hierdie kommunaliteite is bereken deur die faktorladings van elke evalueringskriterium te kwadreer en dit oor die 12 faktore te sommeer. Elke kommunaliteit dien in werklikheid om die proporsie van totale variansie in elke evalueringskriterium, wat deur die geïsoleerde faktore verklaar word, aan te dui. Die kommunaliteit vir elke evalueringskriterium verteenwoordig dus die proporsie van die totale variansie wat deur die 12 faktore verklaar word. Uit Tabel 5 blyk dit dat in die geval van al 65 evaluasiekriteria ten minste $41 \%$ van hul totale variansie deur die 12 geïsoleerde faktore verklaar word; vir 58 evalueringskriteria word meer as $50 \%$ van hul totale variansie verklaar; by 34 evalueringskriteria word meer as $60 \%$ verklaar en by vyf evalueringskriteria word meer as $70 \%$ verklaar.

\section{Faktoridentifikasie : Verbruikerspersepsie van eva- lueringskriteria}

Die 12 faktore wat met behulp van die hooffaktorontleding bepaal is, is geidentifiseer deur na die ladings van die evalueringskriteria op elke faktor te kyk. Die sterkte van die verband tussen die onderskeie evalueringskriteria en faktore, word deur die faktorladings se grootte bepaal. Faktorladings van 0,30 en hoër word gewoonlik as beduidend vir identifikasiedoeleindes beskou (Sheth \& Tigert, 1970; Hair, Anderson, Tatham \& Grablowsky, 1979:234).

Weens die aanwesigheid van relatief hoë faktorladings in hierdie studie, is slegs evalueringskriteria met ladings van 0,45 en hoër by die identifikasie van faktore in ag geneem.

Die 12 geïdentifiseerde faktore word vervolgens afsonderlik bespreek. Die nommer wat by elke faktor voor 'n evalueringskriterium verskyn, is die ooreenstemmende nommer van die betrokke evalueringskriterium in die verbruikersvraelys (kyk Tabel 2).

\section{Faktor 1 : Handelaaroriëntasie}

Die eerste faktor het substansiële ladings ( 0,45 en hoër) op nege van die 65 evalueringskriteria, te wete:

Nr.19 Houding van verkooppersoneel $\quad 0,730$

Nr.52 Reputasie van handelaar $\quad 0,689$

Nr. 4 Verhouding met verkooppersoneel van $\quad 0,686$ handelaar

Nr.33 Reputasie van na-verkope diens

ondersteuning

Nr.32 Vorige ervaring met handelaar $\quad 0,613$

Nr.24 Voorkoms van vertoonlokaal $\quad 0,607$

Nr.60 Ligging van handelaar $\quad 0,497$

Nr.47 Invloed van verkooppersoneel $\quad 0,487$

Nr.41 Uitgebreide handelaarnetwerk $\quad 0,451$

Faktor 1 verteenwoordig 'n kombinasie van 'n verhoudingsdimensie (nrs. 19, 4, 32 en 47) en 'n handelaardimensie (nrs. 52, 33, 24, 60 en 41). Faktor 1 word dus as handelaaroriëntasie geïdentifiseer.

\section{Faktor 2 : Instandhouding}

Faktor 2 het substansiële ladings op ses van die 65 evalueringskriteria:

Nr.15 Lae loopkoste

0,782

Nr. 8 Instandhoudingskoste

0,770

Nr.29 Brandstofdocltreffendheid

0,729

Nr.25 Beskikbaarheid van onderdele

Nr.61 Koste van onderdele

Nr.13 Betroubaarheid van die model

Met die uitsondering van evalueringskriteriumnommer 29 , brandstofdoeltreffendheid, dui die ander vyf op 
koste en beskikbaarheidaspekte van die instandhoudingsdimensie. Faktor 2 word as instandhouding geïdentifiseer.

\section{Faktor 3 : Ruimtegerief}

Faktor 3 laai substansieel op vyf van die 65 evalueringskriteria, naamlik:

Nr.26 Gemak van agtersitplekke $\quad 0,727$

Nr.43 Gerief vir passasiers $\quad 0,696$

Nr.56 Ruimheid vir agterpassasiers $\quad 0,691$

Nr.20 Binneruimte $\quad 0,584$

Nr. 5 Bagasieruimte $\quad 0,451$

Dié faktor verteenwoordig elemente van passasiersgerief en reisgerief en dit word dus as ruimtegerief geïdentifiseer.

\section{Faktor 4 : Bestuursgemak}

Die vierde faktor het substansiële ladings op ses van die 65 evalueringskriteria:

Nr.54 Ruimheid vir bestuurder $\quad 0,774$

Nr.59 Bcenruimte voor $\quad 0,773$

Nr.57 Gemak van bestuur $\quad 0,711$

Nr.49 Rygemak $\quad 0,511$

Nr.63 Tegniese gevorderdheid $\quad 0,494$

Nr.51 Padhouvermoë $\quad 0,465$

Met die moontlike uitsondering van evalueringskriteriumnommer 63, tegniese gevorderdheid, dui al die ander kriteria op bestuursgemak en -gerief. Faktor 4 word as bestuursgemak geïdentifiseer. Kriteriumnommer 51 laai egter ook substansieel op faktor 5. Daar dien op gelet te word dat die feit dat 'n evalueringskriterium substansieel op meer as een faktor laai, nie die nuttigheid van die betrokke evalueringskriterium vernietig by faktoridentifikasie nie (Rummel, 1970).

\section{Faktor 5 : Meganiese werkverrigting}

Substansiële ladings ten opsigte van die volgende vyf evalueringskriteria is by faktor 5 gevind:

Nr.44 Hoëspoedverrigting $\quad 0,709$

Nr.39 Versnelling $\quad 0,622$

Nr.30 Enjinkrag $\quad 0,525$

Nr.21 Werkverrigting van enjin $\quad 0,489$

Nr.51 Padhouvermoë $\quad 0,488$

Hierdie evalueringskriteria dui op duidelike elemente van enjinprestasiekenmerke behalwe in die geval van kriteriumnommer 51, padhouvermoë, waar 'n element van ontwerp ten opsigte van, onder andere, onderstel en vering ter sprake kan wees. Faktor 5 kan gevolglik as meganiese werkverrigting geïdentifiseer word.

\section{Faktor 6 : Voorkoms}

Hierdie faktor het substansiële ladings op vyf evalueringskriteria, naamlik:

Nr. 9 Fatsoen/vorm

$\mathrm{Nr} .38$ Stilering/voorkoms

0,637

Nr. 6 Statusindruk van motor

0,597

Nr.16 Prestigewaarde

0,564

Nr.14 Luuksheid binne
Drie van die evalueringskriteria, te wete, fatsoen/vorm (nr.9), stilering/voorkoms (nr.38) en luuksheid binne (nr.14) verteenwoordig sigbare fisiese kenmerke van die motor. Die ander twee kriteria naamlik, statusindruk van motor (nr.6) en prestigewaarde (nr.16) kan indirekte gevolge van die voorkomsdimensie wees. Hierdie faktor word dus as voorkoms geïdentifiseer.

\section{Faktor 7 : Sosiale beïnvloeding}

Die sewende faktor laai substansieel op vier van die 65 evalueringskriteria:

Nr.17 Mening van kollegas $\quad 0,747$

Nr.46 Mening van vriende $\quad 0,744$

Nr.62 Mening van familie $\quad 0,576$

Nr.48 Radio-advertensie $\quad 0,495$

$B y$ al bogenoemde evalueringskriteria is daar ' $n$ dimensie van beïnvloeding teenwoordig en gevolglik word faktor 7 as sosiale beinvloeding geïdentifiseer.

\section{Faktor 8: Vervaardiging}

Substansiële ladings ten opsigte van drie evalueringskriteria is by faktor 8 gevind:

Nr. 3 Reputasie van motorvervaardiger $\quad 0,659$

Nr. 1 Gehalte van vakmanskap $\quad 0,513$

Nr. 2 Onbeperkte uitsig $\quad 0,512$

Beide nrs. 3 en 1 hou direk verband met die motorvervaardiger terwyl $\mathrm{nr}$. 2 'n indirekte verwantskap met die vervaardiger toon. Faktor 8 word as vervaardiging geïdentifiseer.

\section{Faktor 9 : Keuseversterking}

Faktor 9 laai substansieel op drie van die 65 evalueringskriteria, naamlik:

Nr.42 Toetsrit $\quad \mathbf{0 , 6 6 5}$

Nr.45 Spesiale aanbieding $\quad 0,588$

Nr.34 Padtoetsverslae $\quad 0,505$

Bogenoemde drie evalueringskriteria het ' $n$ dimensie van stimuli wat indirek 'n koper se keuse om 'n motor te koop, kan versterk. Dié faktor word dus as keuseversterking geïdentifiseer.

\section{Faktor 10 : Tegniese voorkeur}

Die tiende faktor het substansiële ladings op twee van die evalueringskriteria:

Nr.64 Voorwielaandrywing

Nr.58 Spieëltjie op bestuurder se sonskerm $\quad 0,503$

Nommer 64 dui op die subjektiewe tegniese voorkeur wat die koper op sy keuse plaas. Nommer 58 is moeilik ten opsigte van hierdie faktor verklaarbaar en moet so aanvaar word. Faktor 10 word dus as tegniese voorkeur geïdentifiseer.

\section{Faktor 11 : Diskonto}

Faktor 11 laai substansieel op oen van die 65 evalueringskriteria:

Nr.27 Kontantafslag

Hier kan 'n diskonto-faktor gesuggereer word, maar kan nie op grond van slegs een veranderlike as sodanig geïdentifiseer word nie. 
Faktor 12 : Reputasie

Die laaste faktor het 'n substansiële lading ook op slegs een van die evalueringskriteria:

Nr. 23 Reputasie van model

'n Reputasie-faktor word hier gesuggereer.

\section{Slotopmerkings}

Uit die 65 evalueringskriteria van die onderhawige studie is daar 12 onderliggende dimensies met behulp van hooffaktorontleding geïdentifiseer, naamlik handelaaroriëntasie, instandhouding, ruimtegerief, bestuursgemak, meganiese werkverrigting, voorkoms, sosiale beïnvloeding, vervaardiging, keuseversterking, tegniese voorkeur, diskonto en reputasie.

Dit spreek vanself dat die 12 geïdentifiseerde faktore vir die bemarkingsbestuur van motorvervaardigers of -handelaars 'n makliker raamwerk daarstel as wat die geval sou wees met die 65 evalueringskriteria. Hierdie faktore kan byvoorbeeld as riglyn by die ontwikkeling van ' $n$ bepaalde bemarkingstrategie soos voordeelsegmentasie, posisionering en reklame deur bemarkers gebruik word.

\section{Summary}

A motor vehicle is a durable item which apart from a dwelling unit represents the most important and single largest expense that a consumer normally incurs. The long-term demand for cars depends, inter alia, on changes in consumer preferences (tastes) and habits. These factors manifest themselves in consumer decisionmaking processes. One of the phases in the decisionmaking process is the evaluation of products. Criteria in the evaluation phase consist of the product's physical attributes as well as subjective factors like values and benefits which are important in the purchasing process.

A study was conducted to establish the underlying dimensions of various evaluation criteria a consumer usually considers when buying a motor vehicle. The sample consisted of 902 consumers of all race groups in mainly metropolitan areas in South Africa who bought a new or used car for private use during the period December 1985 - May 1986.

Sixty-five evaluation criteria were used in a structured questionnaire which consumers had to complete in the dealer's showroom after the deal was closed. Their perception of the relative importance of each criterion was determined on a scale ranging from 1 (totally unimportant) to 6 (extremely important).

A principal factor analysis was carried out on the 65 evaluation criteria and 12 factors were identified.

These factors explained $59,82 \%$ of the variance of all evaluation criteria. Only loadings of 0,45 and higher were considered.

Factor 1 is characterized by items related to dealership aspects like attitude of sales staff, reputation of dealer, appearance of showroom, location of dealer and extensive dealer network. This factor was labelled dealer orientation and had substantial loadings on nine criteria.
Factor 2 is characterized by items related to maintenance: low running costs, availability of spares, cost of spares, maintenance costs etc. A maintenance factor is suggested for this factor.

The other 10 factors identified are as follows: space convenience, driving comfort, mechanical performance, appearance, social influence, manufacturing, choice reinforcement, technical priority, discount and reputation. The last two factors had substantial loadings of 0,45 and higher on only one of the evaluation criteria.

The identified factors provide a simplified framework which can be used as a guideline by marketing managers in the motor industry to develop strategies in regard to benefit segmentation, promotion and positioning.

\section{Aantekening}

$\begin{aligned} \text { 1. Proporsie variansie verklaar } & =\frac{\Sigma h^{2}}{\text { aantal evalueringskriteria }} \\ & =\frac{38,887}{65} \\ & =0,5982\end{aligned}$

\section{Verwysings}

Bloch, P.H. \& Richins, M.L. 1983. A theoretical model for the study of product importance perceptions. J. Market., vol. 47 (Summer).

Boote, A.S. 1981. Reliability testing of psychographic scales. J. Advert. Res., vol. 21, no.5 (October).

Bullock, H.A. 1961. Consumer motivations in Black and White - I. Harv. Bus. Rev., vol. 39 (May/June).

Cohen, D. 1981. Consumer behavior. New York: Random House Inc.

Cox, E.P. 1980. The optimal number of response alternatives for a scale: a review. J. Market. Res., vol. XVII (November).

Dickson, P.R. 1982. Person-situation: segmentation's missing link. J. Market., vol. 6 (Fall).

Du Plessis, P.J. 1986. Verbruikersgedrag by die aankoop. van 'n motorvoertuig. Ongepubliseerde DBL-proefskrif. Pretoria : Universiteit van Suid-Afrika.

Engel, J.F., Blackwell, R.D. \& Miniard, P.W. 1986. Consumer behavior. 5th Edition. Illinois: The Dryden Press.

Hair, J.F., Anderson, R.E., Tatham, R.L. \& Grablowsky, B.J. 1979. Multivariate data analysis. Tulsa, Oklahoma : Petroleum Publishing Company.

Huysamen, G.K. 1983. Psychological Measurement. Pretoria: Academica.

Kaiser, H. 1958. The varimax criteria for analytical rotation in factor analysis. Psychometrika, vol. XXII.

Mulaik, S.A. 1972. The Foundation of Factor Analysis. New York : McGraw-Hill Book Co.

Newsdesk 1982. Results of a major study of the automotive market. South African Associated Newspapers (February).

Newsdesk 1983. Automotive research 1982. South African Associated Newspapers (April).

Newsdesk 1984. The automotive industry. South Africa Associated Newspapers (April). 
Nunnally, J.C. 1967. Psychometric theory. New York : McGraw-Hill Book Company.

Robertson, T.S., Zielinski, J. \& Ward, S. 1984. Consumer behavior. Illinois : Scott, Foresman \& Co.

Rousseau, G.G. 1977. 'n Bemarkingsnavorsingsondersoek na die koopmotiewe van motoreienaars in die Suid-Afrikaanse motorhandel. Humanitas, RSA, vol. 4-2.

Rummel, R.J. 1970. Applied factor analysis. Evanston, Illinois: Northwestern University Press.
Sheth, J. \& Tigert, D.J. 1970. Factor analysis in marketing. Chicago, Illinois : American Marketing Association Workshop on multi-variate methods.

Stewart, D. \& Hood, N. 1981a. A methodology for the evaluation of segmentation policy : an empirical application in the car industry. J. Market Res. Soc., vol. 23, no. 3.

Stewart, D. \& Hood, N. 1981b. East European competition in the UK car market : some empirical evidence. Europ. J. Market., vol. 15. 